\title{
The Role of Literary Content for Children in Preschool Mathematics Education
}

\author{
Sanja M. Maričić ${ }^{1 *}$, Mirjana M. Stakić ${ }^{1}$, Nela T. Malinović-Jovanović ${ }^{2}$ \\ ${ }^{1}$ University of Kragujevac, Teaching Training Faculty in Užice, SERBIA \\ ${ }^{2}$ University of Niš, Pedagogical Faculty in Vranje, SERBIA
}

Received 1 May 2017 - Revised 29 August 2017 • Accepted 2 October 2017

\begin{abstract}
In this paper, authors point out the need and possibilities of integrating content from literature for children into the process of preschool mathematics education. On concrete examples of various forms of literature for children (picture book, poetic text, story, fairy tale, numerator) point out the role of these contents in the process of learning and building mathematical concepts in preschool mathematical education. The contents from literary for children are viewed as a starting point in the work on mathematical education activities whose role is to create a real-life context, which is close to the child, in which the child is accustomed, in which the child is motivated to participate, as content that excites curiosity and interest in learning of abstract mathematical concepts, and which visualizes mathematical concepts and helps crossing from concrete performances to abstract mathematical performances.
\end{abstract}

Keywords: integration, literature for children, mathematics, preschool mathematics education, language development

\section{INTRODUCTION}

Mathematics education of preschoolers differs from adult learning. It is "spontaneous, unobtrusive, initiated by the curiosity of the child, placed in a realistic life context, less consciously and with less intentions from adult learning, with little ability of verbalization and symbolization, limited to practical actions and perceptions, with a large part of imagination and richness of iconic representation" (Purić, Maričić, 2012: 239). The development theories of the intellectual development of a child of preschool age describe a period in which children have a modest logicalanalytical apparatus, they are perceptively linked and fixed for the context in which they learn; they have problems with abstraction and expression because of the limited vocabulary and underdevelopment of language possibilities; they need the specific activities and the picturesque way of displaying and marking things and phenomena, but also as a period of rich developmental potentials where memory and intense sensory motor stage and iconic development dominate (Guidelines on the Basis of Preschool Curriculum, 2006: 26). On the other hand, this period of mathematical education is very important, both for the process of further mathematical education, and for the overall child's cognitive development. Thereby, it is noted that early mathematics education helps children to develop a mathematical foundation, as well as to increase the quality of the mathematics classroom environment (Clements \& Sarama, 2008), and that a high-quality preschool education can improve math and literacy competencies for all children (Bridges, et al., 2004). The National Council of Teachers of Mathematics (NCTM) and the National Association for the Education of Young Children (NAEYC) affirms that "high-quality, challenging, and accessible mathematics education for 3- to 6-year-old children is a vital foundation for future mathematics learning (2002: 1). The numerous researchers confirm this fact and point out that preschool mathematics education is the basis for later mathematics' improvement at school. (Claessens et al., 2009; Krajewski \& Schneider, 2009) and that the kindergarten mathematical knowledge was the most important set of skills for later achievement, followed by kindergarten literacy, and attention skills, respectively (Claessens et al., 2009). 


\section{Contribution of this paper to the literature}

- The aim of the paper is to point out the role and function of literature content for children in preschool mathematics education.

- The paper shows how literature content for children create a real context that is close to the child, as a basis for learning and adopting mathematical content in preschool mathematics education.

- The paper presents the options which offer various forms of literature for children: picture book, poetic text, story for children, fairy tale and abacus in the process of preschool mathematics education.

\section{INTEGRATIVE APPROACH IN PRESCHOOL MATHEMATICS EDUCATION}

The question is how to organize the process of mathematical education in preschool age, how it can be in compliance with the child's learning abilities and interests, and to result in the best achievements. The researches of the preschool child's learning and development point to the fact that children cannot learn in the isolated subject disciplines, and that the successful development of initial mathematical concepts cannot occur if they are isolated in special learning situations. Accordingly, it is pointed out that "if educators direct learning to the subject areas, then the effects of such learning will be isolated skills and contents that do not lead to the development of mathematical concepts" (Ćebić, 2009: 45). The recommendations of National Association for the Education of Young Children (NAEYC) and the National Council of Teachers of Mathematics (NCTM) are directed to "integrate mathematics with other activities and other activities with mathematics" (NAEYC, NCTM, 2002: 7). These recommendations are in compliance with the ideas of constructivist and social constructive theories according to which the process of learning is the process of the active construction of knowledge and development of the child, and not simply the transfer and the idea that learning is a social activity in which language and communication play a key role (Rogoff, 1990). Therefore, the process of learning within preschool mathematics education should be observed as holistic one. Such learning organization requires, above all, an integrated approach in which children "explore, spontaneously adopt mathematical concepts within a wider thematic unit, embedded in a particular context, which is often pervaded by play and by abundance of contents from different subject areas" (Maričić, Purić, 2013: 390).

Math concepts are "better understood when they are a part of the daily activities” (Jackman, 2012: 159). That means that the development of mathematical concepts cannot be considered isolated in relation to other areas of knowledge - speech development, music, physical and artistic education, environmental awareness, as well as everyday activities that form an integral part of the child's activities. The process of developing mathematical concepts must be placed in a realistic context, a child is motivated to participate in learning, and the learning process is stimulated by the internal initiatives of the child. Young children do not perceive their world as if it were divided into separate cubbyholes such as "mathematics" or "literacy" (NAEYC, NCTM, 2002: 7). The preschool mathematics education should be observed as part of an integrated curriculum which is designed to help each child to reach her/his potential, instead of isolating mathematics in the field of academic content (Arias de Sanchez, 2010).

There are numerous advantages of an integrated curriculum. Learning within the integrated approach provides opportunities for more relevant, less fragmented and more stimulating experiences for children (Frykholm \& Glasson, 2005; Koirala \& Bowman, 2003). In this way, the usage of mathematics in different contexts becomes more emphatic (Whitin \& Whitin, 2004) provides meaningful, authentic learning (Clements et al., 2003; Kilpatrick et al., 2001). And National Association for the Education of Young Children and the National Council of Teachers of Mathematics point out "important is weaving mathematics into children's experiences with literature, language, science, social studies, art, movement, music, and all parts of the classroom environment" (NAEYC, NCTM, 2002: 7). Such type of work helps students to use mathematics to connect to their own lives each day. In this paper we want to draw attention and point to the role of literary content for children in preschool mathematics education.

\section{CHILDREN'S LITERATURE IN PRESCHOOL MATHEMATICS EDUCATION}

Numerous research papers have found many benefits to integrating mathematics into children's literature. This approach motivates children to participate in activities that contribute to the creation of mathematical knowledge, contributing to the formation of positive attitudes towards mathematics (Huppert, 2012), primarily because of the context in which learning is placed. The research results show that the integration of children's literature content and activities aimed at the development of mathematical concepts also contribute to the improvement of mathematical knowledge in the classification (Hong, 1996), measurements and measures (Van den HeuvelPanhuizen, \& Iliada, 2011; Whitin \& Gary, 1994), geometry (Hong, 1996; Rosen \& Hoffman, 2009; Skoumpourdi \& 
Mpakopoulou, 2011). On a wider scale, the literary contents motivate children to learn, to show that mathematical knowledge can be acquired based on human experience (Whitin \& Wilde, 1992).

We can consider the importance of integrating literature for children into initial mathematics education from two aspects: the child's aspect and the context of learning aspect (Maričić, Purić, 2014: 178).

From the aspect of the child, "literature provides a personal learning experience in which children can enter the story from their level of mathematical curiosity" (Jenner, 2002: 160). The literature for children was written for a special readers' audience - children. Because it has a specific recipient, its theme, style and language is also specific. "The theme in literature for children has the advantage over the form, language and way of shaping artistic material" (Stakić, 2014: 244). The basic thematic essence of the literature for children presents: nature, childhood, the world in which a child lives, plays, grows and develops. The dimension of space and time in it has secondary significance, since child imagination has unlimited power (Milinković, 1999: 13). The ability of the child to fully enjoy situations in which the erased boundaries between the imaginary and the real allows him/her that during the reception of the literary work, to become a participant of the subject matter, which allows "his/her true, lifecreatively play in which the imagination and reality are not separated" (Marković, 1987: 6). The literature for children therefore characterize "conceived, humane and cheerful content" (Petrović, 2011: 8) and topics that are devoid of pessimism (Marjanović, 2009). Its dominant marks are: game, joy, freedom, life, magic, imagination and humor. Their reception is based on the thoughtful and emotional element, because children in response to the literary work react emotionally, sensitively, creatively, thoughtfully and ethically (Stakić, 2013: 507).

The literary text with its content creates a context that produces activities related to mathematics. That context is understandable and close to the children, real and concrete, creates the basis for abstraction and provides a gradual transition from concrete performances to the abstract level and symbolism of mathematical ideas, so that content from children's literature "mediates between the child and the language code of the mathematical concept" (Purić, Maričić, 2012: 241). Furthermore, those contents help children to understand the meaning of concepts in different contexts, create opportunities for further research on mathematical concepts from the point of view of the child's personal perception, and at the same time provide an illustration of mathematical ideas (McDuffe \& Young, 2003). All of that is being achieved by the theme of content that is picturesque and adapted to the child's understanding of the world. "Connecting math with children's literature is an ideal strategy for supporting learning" (Whitin \& Whitin, 2004). Children's literature has been widely described as a tool to provide hands-on opportunities to apply math concepts and skills (Kolstad et al., 1996; Moyer, 2000; Smith, 1995; Whitin \& Gary, 1994).

The literature for children enables the placement of mathematical content into a context that makes sense for children (Hong, 1996) and the perception of mathematical content and problems as part of a real life context (Lowe \& Matthew, 2000; Usnick \& Maxson, 1996). In such context, the child explores, observes mathematical objects in a real, close environment of his/hers. Exposed to the work of the literary part the "children take mathematical ideas from literary content, use them in situations that are close to them, and then these contents open problems for which the solution is intricately motivated to solve them" (Maričić, Purić, 2014: 178). The literary characters become real, and their problems can be compared to children's problems, because children emotionally empathize with the illustrated reality of the literary text "and identify with the heroes; they are happy when the heroes are happy, share their suffering, fear and pain" (Stakić, 2013: 507). Thus, the literature places mathematics in circumstance "close to children, with which they can be identified and which they considered important and interesting" (Schiro, 1997: 10).

Children's literature books should have authentic context that includes life experiences, personal or cultural episodes, and enjoyable plots that unite mathematics and literacy (Worley, 2002). The mathematical concepts in literary texts are presented by words, not by mathematical symbolism, which make them close to the child. Bearing in mind that a word is the last element in the process of constructing of mathematical term, that it is the bearer of the content of the term, then the significance of the literary text in the process is even more distinctive. The word is "the verbal bearer of the essence of the term. The physical experience is internalized, and the word helps thought to be generalized" (Šimić, 1998: 61). The words that mark mathematical terms present abstractions for a preschooler and children adopt them with difficulty, and even more difficult understand and adopt their meaning. Those literature contents for children can mediate between the child and the language code of the mathematical term. This mediation is enabled through the literary text as a concrete linguistic template that creates a real context which is close to the child, understandable to him/her, in which he/she get accustomed, because he/she visualized it in his head. Children use this mathematical term in the context of solving problems that make sense to them and from the external speech moves slowly into the internal one. The literature content for children in learning and adopting mathematical content, in (Welchman-Tischler, 1992) opinion, contribute in providing context and activities of the mathematical content, introduce manipulative that will be used in varied ways (not necessarily as in the story), present the mathematical problem to the child in an interesting way, prepare for the mathematics concept or skill, develop or explain the mathematics concept or skill. Purić and Maričić point out that the contents of literature for 
children contribute to: 1) stimulating interest, curiosity, motivation for thinking, discovering and adopting mathematical concepts; 2) putting mathematics and mathematical concepts into a real life context; 3) visualization of mathematical concepts, which is achieved by the thematic-motivational structure of literary content; 4) creating clear mental perception that enables the development of mathematical concepts in the learning situation, which is natural for the child, spontaneous and unintegrated from the outside; 5) easier and faster adoption of the name of abstract mathematical concepts, because the linguistic expression of mathematical terms is incorporated into the content of literature for children; 6) correlation and integration of the development of initial mathematical concepts and speech development (2012: 240).

Numerous literary books for children can play a role in the preschool mathematical education, starting with children's picture books, through poetic texts, stories, fairy tales, short oral forms and dramatic texts. We will show concrete examples of these contents and how they can be used in working with children within preschool mathematics education.

\section{Picture Books in the Function of Mathematical Education}

Picture books present the first content of literature for the children that they meet and the first books that mark their childhood and growing up. According to their basic purpose, "they should get the youngest readers close to literary text, art and music" (Milenković, 2012: 117). In the picture books that are dedicated to children, there are more pictures and they serve children mostly as toys. But the picture is a favorite way for a child to learn the world and communicate with others (Scott, 2005). Through a picture book, a child becomes acquainted with the world (landscapes, plants and animals), relationships, rules of conduct, means of transport, occupations, games, etc. It helps him/her to better understand the content of the text, improvise or dramatize it. Bearing in mind that through the picture books one of the first levels of literary and art communication with the child is realized, which he perceives spontaneously and unobtrusively as a play, that the picture books "visualize space and time and give the experience of the whole and the details" (Milenković, 2012: 117) and to contribute to the abstract thinking and adoption of symbols (Petrović, 2011), numerous authors emphasize their role in early mathematics education. Picture books captivate children's interest in mathematics, help them to make mathematical connections because it provides visualizations of mathematical concepts in the form of illustrations (Shatzer, 2008; Whitin \& Whitin, 2004) and make context for learning mathematics' terms. (Columba, 2013; Golden, 2012; Whitin \& Whitin, 2011). The research results show that picture books contribute to a better, more complete and more universal use of mathematical vocabulary and improve communication (Jennings et al., 1992; Golden, 2012; Kurz \& Bartholomew, 2012; Ward, 2005), then contribute to better mathematical achievement (Hong, 1996), improve attitudes towards mathematics (Burns, 2010; Tucker, et al., 2010). However, the research shows that their representation in the process of mathematics education is low (Van den Heuvel-Panhuizen, et al., 2016). The use of picture books in mathematics "provides students opportunities to apply their knowledge while solving problems, thus fostering critical thinking skills, a necessary skill for the use of mathematical knowledge in real world situations" (Stone, 2016: 23). Picture books have "potential to act as a magnifying glass that enlarges and enhances the reader's personal interactions with a subject" (Vacca \&Vacca, 2005: 161).

In order to fulfill their function in preschool mathematics education, it is important to choose the picture books properly. The educator must select carefully the picture book bearing in mind, above all, the aim that he wants to achieve in the field of mathematics learning. For example, the contents of the following picture book (Figure 1) can be used for perception, spotting, selecting and naming of positions left-right, front-behind-between (What's left / right of a girl in a yellow sweater? What is behind her? What is in front of, and what is behind the shepherd? Who is located between the girl and the boy, etc.), but also for recognizing size ratios: high-low (comparing children's height).

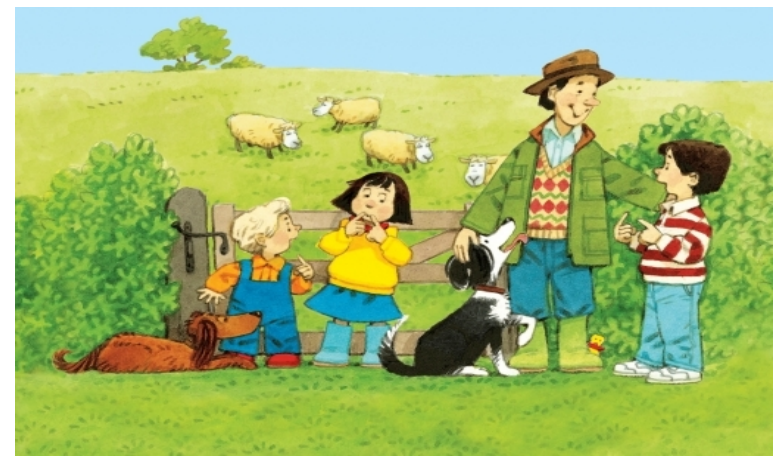

Figure 1. Amery, H., Cartwrightom, S. (2017). Farmyard Tales Storybooks, Planeta Zoe. 
In addition, the picture creates the context in which children notice sets of events (a set of children, a set of sheep, a set of dogs, a set of shepherds), recognize and name their elements, and sets can be compared in number.

\section{Poetry for Children in Preschool Mathematics Education}

Poetic texts intended for children of preschool age provide numerous opportunities in adopting mathematical content, too. Their basic motive essence presents the childhood and immanent child's characteristics: joy, happiness, play, freedom, friendship, growing up, etc. The topics in children's poetry are in the fields of interests of a child of this age, everything that surrounds him, everything he wants and everything he fantasies about (toys, teddy bears, children, moms, dads, grandmas, granddads, houses, cats, bunnies, butterflies, dolls, balls, pirates, hunters, sailors ...). Things, phenomena, beings, objects and everything that exists in the child's world is presented from the child's point of view, understood by his/her logic, by his/her vision of the world, is unexpected and unusual. The poetic texts intended for children are written in a way that is understandable to the child. The language expression is clear, it does not contain symbols, metaphors, and other stylistic expressions, which by transferred meaning, would disturb the understanding of the poetic text. The specificity of the stylistic language expression is achieved by the association power of certain voices, and the games with voices and words present a way to achieve the reception (Milinković, 2012a).

The close bond between the poetic text and the child is ensured by the specific structure of the poem, which is based on the emotional and thought element which is close to child. The lyric poem was created as "an imalowege, emotionally intonated, as a music of a poetic speech that expresses the poet's inner world" (Rosandić, 1984: 22). Melodiousness and musicality, clarity of expression, picturesqueness, expressiveness, layering and suggestiveness contribute to that poetic text comprehensively engage the child, attract his/her attention, stimulate curiosity and draw him/her into its contents, which is crucial for the process of learning at preschool age. Besides, child additionally develops the existing poetic paintings by his/her own views, and the absence of real, acquired experiences replaces and extents to the inexhaustible richness of imagination, imaginative paintings and combinations (Maričić, Purić, 2008: 204). The child experiences the world of poetry completely, syncretic, as a unity of visual, audible, rhythmic, kinesthetic and fantasy elements. Accordingly, experiencing the rhythm is related to movement, sound, real or imagined visual elements, all of which are transposed to the game plan - motion games, sound games, word games. The meaning the rhythm for the child is almost magical (Maričić, Purić, 2008: 205). All of that leads the child to the world of game and creates a special magic.

The poetic text, in the first place, provides a context for learning mathematics, which is a key reason for connection between literature and mathematics (Haury, 2001). This context is close to the child, perceived by his vision of the world, and the child places himself/herself in that context. For example, the poetic text Four Girls, precisely by its content, provides the context that creates the basis for developing the term of number four.

Four Girls

A mum walks down the street with her four girls

Mum says

-I'm going to buy a bag

And four girls say

-And four small bags. And four small bags

Mum says

-I'm going to buy a big comb

And four girls say

-And four small combs. And for small combs.

Mum says

-I'm going to buy a big scarf

And four girls say

-And four small scarves. And four small scarves.

Mum says

-I'm going to buy a scrub brush.

And four girls said nothing. (Lukić, 1967, 127-128)

The poet through the verses of the song creates a context close to a child: a mum walks down the street with her four girls, talks to them about what she intends to buy. This is a situation where children often find themselves in their life. The song is written as a dialogue between mum and the girls, which not only approaches it content to the child, but also creates the possibility for stage performance. In such situation, the children (four girls) and the 
requisites enter the scene: four small bags, four small combs, four small scarves from which sets of four are formed. In an obvious way, it is possible to determine the equivalence of formed sets, by joining the elements of set of combs, scarves, and bags, to the set of girls. Based on formed sets, children get a mental presentation of a set of four elements, and through which, by the word of FOUR, comes the term of the number four (Figure 2). Silence of the girls from the song on their mother's words: I'm going to buy a scrub brush, can present a motive for bringing children into the activity of self-forming sets. Children are, for the mentioned activity, motivated by the question: How many small scrub brushes should mum buy for her girls, so each girl has one brush? The activity of forming the sets whose cardinal number four is realized by the didactic material found in the study room. That introduces children into activity of self-forming sets of didactic materials that they possess in a study room, whose cardinal number is four. In this way, the formation of the term number four places itself in the real context, the child recognizes the number as part of an objective reality, the term of the number is concretized here, but at the same time it is possible to gradually move to the abstraction of the non-essential properties and to retain the cardinal number of the set as a sign of the term number.

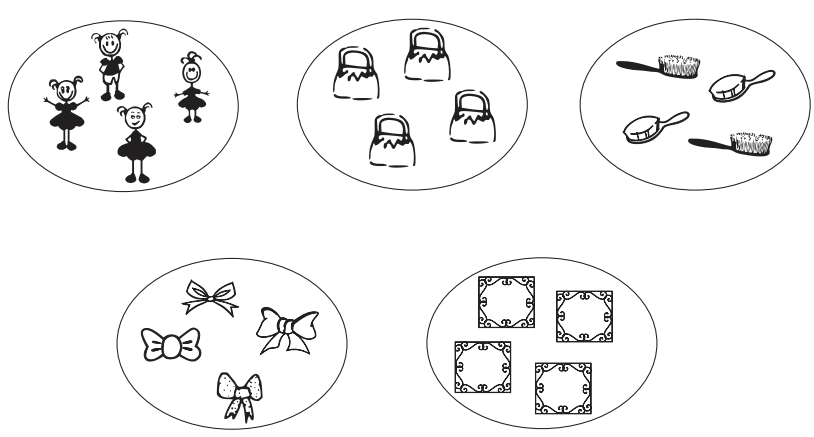

Figure 2. Examples of sets

The content of the poem, besides that it creates and visualizes the context for the development of the term number four, it also abounds in the word four as the carrier of the term number four. Using the same word for perceptively different contents (four girls, four small bags, four small scarves, four small combs), the child notices what is common for the sets - they have four elements. On the other hand, we have examples of sets of one element (one mum, one big bag, one big comb, one big scarf, one brush). This situation can be used to compare a set of one element to a set of four elements, which is later transferred to the comparison of the number one to the number four. There are numerous examples that the educator can use in the process of initial mathematics education.

\section{Story as a Supportive Tool in Preschool Mathematics Education}

Apart from the poetic texts, the stories also represent content that can be in the function of mathematical education in the preschool period. They "make the information better to remember because they involve us in actions and intentions of characters" (Malinović-Jovanović, Milojević, 2013: 181). The story for children characterize a specific thematic structure. It must be interesting and exciting to the child, to motivate and keep his/her attention by unexpected and dynamic action, so there are a few episodes and minor characters in it (Stakić, 2014). Children are closely related to animals in the role of literary heroes, they are closely related to the characters of children or their peers. Their characterization is often accomplished in a humorous way because laughter is essentiality tissue of literature for children. Stories in the mathematics classroom are that they can assist in understanding difficult concepts and ideas, and assist in solving problems" (Zazkis \& Liljedahl, 2009: 4). The primary function of the story is to awake child's curiosity, to encourage him/her to solve the problem, and also to create an obvious context for learning. They "allow us to incorporate new knowledge, to expand our perspectives and opportunities, because we meet them in the familiar area of human experience" (Malinović-Jovanović, Milojević, 2013: 181).

For example, the short Russian folk narrative story of The Giant Turnip is an excellent basis for introducing the relation of positions (in front of, behind, between).

\section{The Giant Turnip}

Once, not too long ago, an old man planted a turnip. The turnip grew, and grew, and grew some more until it was enormous. The old man started to pull the turnip out of the ground. He pulled and pulled, but it was just too big for one man alone. So he called his wife to help. The old woman took hold of the old man, the old man took hold of the turnip and they pulled and pulled, but could not pull it out. The turnip was just too big. So the old woman called her granddaughter to help. The granddaughter took hold of the old woman, the old woman took hold of the old man, the old man took hold of the turnip and they pulled and pulled. But the turnip was just too big and they could not pull it out. So the 
granddaughter called the dog over to help. The dog took hold of the granddaughter, the granddaughter took hold of the old woman, the old woman took hold of the old man, the old man took hold of the turnip and they all pulled and pulled. But still they could not pull the turnip out. So the dog called the cat over to help. The cat took hold of the dog, the dog took hold of the granddaughter, the granddaughter took hold of the old woman, the old woman took hold of the old man, the old man took hold of the turnip and they pulled and pulled. It seemed impossible, but still they could not pull it out. So the cat called the mouse over to help. The mouse took hold of the cat, the cat took hold of the dog, the dog took hold of the granddaughter, the granddaughter took hold of the old woman, the old woman took hold of the old man, the old man took hold of the turnip. They all pulled and pulled, and pulled some more -and finally out came the turnip!

The content of this story is interesting for children: the grandfather cannot pull a giant turnip out so he calls the grandmother for help. A series of assistants in pulling the turnip out in the story is successively lower, as each of the assistants calls a new one for help. Children's laughter is caused by the fact that animal assistants call animals for help with which in the natural world they are in a relationship of antagonism and hostility. Children are aware that cats can't stand dogs as well as that cats catch mice. In the personalized world of the story the animals work together with one another for the same purpose: to help a man. The story of The Great Turnip, has not only the elements of a humor, it also educates the child of preschool age, because in its reflexive layers it has a deep ethical message about overcoming hostility, assistance and cooperation that unites and connects those who have the same goal.

The story of The Giant Turnip is suitable for dramatization, it helps creating a clearer context for introducing the relation of the position in the space. Children are involved in dramatization and they notice the relations in which they are towards others and others towards them. They get the roles in which they identify themselves with the heroes of the story. In this way, at the same time, developing creativity and imagination, children on the scene, directly and spontaneously, notice the relations they have with others, and the relations that others have towards them: they notice who is in front of the small actress in the role of the grandmother, who is in front of the girl, but who is also on the scene between the grandfather and the girl. The play of dramatization, children experience as a reality because in moments while it lasts, they play a role, and the boundaries between reality and imagination are being annulled. The aforesaid shows how the content of story gradually and unobtrusively goes into a real context and notice shown relations towards children, which the educator lines in the series similar to the series in the story. They now clearly notice who is behind the grandfather, who is behind the grandmother, etc. They also notice who is in front of the grandmother, in front of the girl, but also who is between the grandfather and the girl.

\section{The Role of Fairy Tale in the Development of Mathematical Concepts}

One of the prose types, the child of preschool age finds interesting is a fairytale. It presents the most important literary genre in literature for children (Milutinović, 2016: 246). "From the tissue of imagination, the tissue of dream, a fairy tale creates its world" (Olujić, 1982: 23). Childhood, according to Milinković, is the phase of life "which can be considered the most suitable world of miraculous and direct, in the sphere of naive fantasy" (2012b: 82), and Vuković describes the whole period of preschool age as "a period of fairytales" (1996: 39). Fantasy and imagination make fairy-tale an interesting world of a child. The imagination leads the child through the world of fairy tales, it experiences the adventures of the main characters and looks forward to its happy ending. Everything is possible in it, just as it is in the game: animals, plants and objects speak, and children have an expressive need for personalization of objects and phenomena (Petrović, 2005). However, the fairy tales also have a highly educative message. In spite of all the challenges, in the fairy tales good always wins. The fairy tale teaches the child that he/she shouldn't give up of his/her dreams and desires, and they should work and act in order to achieve them: the fairy-tale hero crosses the "seven seas" and "seven mountains" to fulfill his dream. Bettelheim points to the importance of fairy tales, "because they reveal life as it is perceived or felt from the inside" (1976: 101). Fairy tales "they deal with real problems in the most magnificent way, they figure out life and illustrate internal conflicts of one character" (Smiljković, 2006: 23). They develop children's imagination and aesthetic sensitivity, from the aspect of the development of speech, they enrich their vocabulary, they are suitable for retelling exercises and creative telling and they present a template on which various forms of dramatization can be organized that free the children of jitter and fear, they develop diction and stimulate features of good speech. The content of a fairy tale makes the world exactly what the child imagines and understands. In fairy tale the rational and irrational is interlaced, dreams, imagination, everything is possible and impossible, and the child experiences realistic as same as unrealistic feelings. The child believes in everything, because it has no elements of causal, logical thinking. The fairy tale themes are the fantastic events placed in unusual landscapes, its heroes are unusual people, the personalized world of nature, wonderful beings, often revived objects, everything is placed in indefinite time and space, which creates the impression with the child that miracles are possible and that they really happened (sometimes in a 
distant country...). An optimistic message of a happy ending is a continuation of the belief that miracles are possible and that good wins.

Numerous fairy tales can play a role in the process of forming mathematical concepts with preschool children. For example, the content of the fairy tale Three Little Pigs creates an excellent real context for the formation the term of number three (three pigs, three houses, three doors on houses). From the standpoint of the development of speech, this fairy tale is a good language template for performing the description exercise. The educator introduces children into the process of analytical description based on the game of visualization where the external appearance of the house and the material from which it is made, they connect the character features of the animal heroes who are their creators. The educator can also ask children to compare the appearance and interior of the houses that the heroes built. Describing thus becomes more complex, children develop the power of observation and comparing and memory, and it also significantly contributes to their language development from the aspect of lexical and syntax, because it is necessary for the children to compare the exterior and interior into coherent, clear and correct sentences.

Also, the Little Red Riding Hood fairy tale creates an excellent real basis for the development of the term of number one, as there are numerous examples of one-element sets that can be distinguished from the content of a fairy tale (one Little Red Riding Hood, one wolf, one grandmother, one hunter, etc.). In the same way, the fairy tales The Snow White and the Seven Dwarfs and The Wolf and the Seven Little Goats can be used to form the term of the number seven. The aforementioned fairytales can also be used to form the term of the number eight, in which the idea of axiomatic, numerical approach in the formation of the concept of a natural number is based on the idea of adding one by one (seven dwarfs plus a Snow White total is eight $(7+1=8)$, seven goats plus a wolf, total is eight). The fairy tale Goldilocks and the Three Bears also provide a good basis for the formation of the term of the number three (three bears, three chairs, three beds, three plates, three spoons, etc.), but also an excellent context for developing the term of size relations of big-little, for marking relation of big-bigger-the biggest, little-less-the least, and for the establishment of a series (decreasing or rising), but also for the size conservation. There are many other fairy tales that can be used in the context of mathematics learning in preschool education.

\section{A Number Counting in Preschool Mathematics Education}

The number counting and rhyming words are specific speech games. They consist of non-sense groups of voices or words that children find difficult to pronounce and represent typical models of non-sense speech which are over presented with coinage from oral tradition (Milinković, 2012b). Although they are, by their origin, very old, it is considered that they originated from the practical need to split something, they are now mostly associated with the world of childhood and children's games. Children use them in game situations, on occasions when it is necessary to start the game or determine who will have a role in it. The number counting is "most often related to the beginning of the game, they can be the content of the game itself, as well as the language game" (Maričić, Purić, 2010: 181). It often appears in a rhyming form and its elements are embedded in contemporary poetry for children. The number counting is characterized by "simple theme, unexpected situations, unexpectedness and wonderfulness, which in cooperation with the rhythm, lead to fantasy" (Maričić, Purić, 2010: 180). Children love the numbers counting, they are easy to remember because of the rhythm that is close to their sense of music. In preschool institutions, educators use them in the development of speech as a kind of artistic exercises that helps children to pronounce vowels properly. The numbers counting can be used in the process of preschool mathematics education. For example, the number counting Let's count contributes to the development of a numerical order from one to ten, developing counting ability up to ten and counting backward from ten to one, as well as adopting and memorizing the first ten numbers.

Let's count

One, two, three, four, five, six, seven, eight, nine, ten

Ten, nine, eight, seven, six, five, four, three, two, one

We now know our number from one to ten

It's no problem to count again and again

Can you believe we come to the end?

I loved learning numbers with you my friend.

This number counting can be used in numerous activities that are related, primarily, to the free children's activities and the game. The children, by telling the number counting, master the procedure of counting the elements of the set. In this way they associate mathematics with daily activities, understand the role of counting, engross counting as an activity that is very important for understanding the concept of a number. 


\section{CONCLUSION}

Mathematics, although at first glance, looks like a science which is built on a purely abstract level, it is the science that operates exclusively with symbols, whose language is a system of special signs (symbols) that is understandable to everyone, is certainly built in a real context. The construction of mathematics, as a science, starts in the preschool period when the child starts the construction of mathematical knowledge for the first time. The contents of the preschool mathematics are the contents of mathematics as a science (sets, numbers, relations, geometry, measure and measurements), but their transformation at preschool age is based on the experience of children, the environment in which he/she lives, plays, grows up. The child acquires mathematical contents in the process of activity on the contents that are close to him/her, into which the child participates, in which the child perceives the elements, correlations and relations among them. It is the process that is not isolated from other activities in a preschool institution, but is well integrated with different areas of knowledge. The key moment on which it is based is to stimulate the child's interest and curiosity in order to participate in the activities.

Literature for children provides a motivational basis for organizing activities in kindergarten that are focused on the learning of mathematical content. Through its thematic structure, all the life that is familiar to the child is reflected, in which the personally experienced knowledge is expressive, also the world of imagination and fantasy, in a few words, everything for which the child longs and wants.

Children engross the content of literary texts, identify with heroes and together with them go through adventures and share their joy or sadness, unconscious of process that is happening. The literary text changes the child: through its theme the child enriches himself/herself, develops imagination, aesthetic taste and sensibility, matures and ethically enriches the personality. It all happens spontaneously. The child unconsciously enjoys and imagines, and at the same time the child learns. Research shows that "preschool children with disabilities increased their skills in math after an intervention integrating mathematics within children's literature" (Green, 2014: 137).

In the paper we have presented only some of the possibilities regarding the usage of literary texts of different literary types in preschool mathematical education. Their range and effects are conditioned by the very theme of the literary text. Therefore, besides to aesthetic value, the theme is the first valued criterion that determines whether the literary text is applicable and to what extent in the preschool mathematical education.

Therefore, the first task of the educator is the proper choice of literary text. It starts from the specific aims of preschool mathematics education which are to be realized by the appropriate content of literature for children. Secondly, the literature contents cannot be just an isolated means of realizing the aims of the preschool mathematics education. That means that they must be observed both from the literary aspect and from the aspect of development of speech, which additionally complicates the choice of the suitable literary text. It must be adapted to the age of the child, his theme must be close and interesting to the child, the text must be clear to the child. The text must be discussed, it must be analyzed before, all unknown words must be explained to children in an adequate way. Therefore, the literary text must not be unknown or strange to the child. Its reception is necessary. Experiencing, understanding and accepting the literary text is a necessary condition for the child to demonstrate and create a real context for the adoption of the initial mathematical concepts that appear in the text. They are not perceived as isolated categories but as components of a complex meaningful text structure.

The reaching towards them is accomplished by conversations about the literary text, which is an introduction to various play activities, as this paper presented the play of dramatization The Giant Turnip, in which the acquisition of initial mathematical knowledge is realized in integration with the development of speech.

Besides the considered possibilities offered by picture books, poetry texts, stories for children, fairy tales and number counting, it would be necessary to consider the theoretical possibilities of other literary types that are close to the reception of a child of preschool age: short speech (gestures, puzzles, proverbs...), fables and stories about animals. Enlightening their genre characteristics in the context of initial mathematics education would contribute to a more comprehensive consideration of the importance that the literary text has as a supportive tool in preschool mathematical education. Integrating the aims in the development of speech with the aims of preschool mathematics education is an important task, but also a challenge for everyone who works in preschool education.

\section{REFERENCES}

Arias de Sanchez, G. (2010). The use of worksheets in early childhood mathematics education. In R. Doiron \& M. Gabriel (Eds.), Research in early child development in Prince Edward Island: A research monograph (127-139). Charlottetown, PE: Centre for Education Research, University of Prince Edward Island.

Betelhajm, B. (1976). Značenje bajki. Beograd: Zenit.

Bridges, M., Fuller, B. C., Rumberger, R., \& Tran, L. (2004). Preschool for California's children: Promising benefits, unequal access. PACE Policy Brief, 04-3, Berkeley, CA: Policy Analysis for California Education (PACE). 
Burns, M. (2010). As Easy as Pi: Picture Books Are Perfect for Teaching Math. School Library Journal, 56(5), $32-41$.

Claessens, A., Duncan, G., \& Engel, M. (2009). Kindergarten skills and fifth-grade achievement: Evidence from the ECLS-K. Economics of Education Review, 28, 415-427.

Clements, D. H., \& Sarama, J. (2008). Experimental Evaluation of the Effects of a Research-Based Preschool Mathematics Curriculum. American Educational Research Journal, 45, 443-494.

Clements, D. H., Sarama, J. \& DiBiase, A. M. (2003). Engaging young children in mathematics: Findings of the 2000 National Conference on Standards for Preschool and Kindergarten Mathematics Education. Mahwah, N. J.: Erlbaum.

Columba, L. (2013). So, Here's the Story. Teaching Children Mathematics, 19(6), 374-381.

Ćebić, M. (2006). Poč́tno matematicko obrazovanje predškolske dece. Beograd: Uciteljski fakultet.

Frykholm, J. \& Glasson, G. (2005). Connecting science and mathematics instruction: Pedagogical context knowledge for teachers. School Science and Mathematics, 105(3), 127-141.

Golden, L. (2012). Children's Literature in Mathematics Instruction. Library Media Connection, 31(2), 40-41.

Green, K. B. (2014). The effect of the integration of mathematics within children's literature on early numeracy skills of young children with disabilities (Dissertation), Georgia State University. http://scholarworks.gsu.edu/epse_diss/93.

Guidelines on the Basis of Preschool Curriculum. (2006). Belgrade: Educational Review.

Hong, H. (1996). Effects of mathematics learning through children's literature on math achievement and dispositional outcomes. Early Childhood Research Quarterly, 11, 477-494.

Huppert, E. (2012). Integrating Children's Literature into the Mathematics Classroom. Vanderbilt University.

Jackman, H. (2012). Early Education Curriculum: A Child's Connection to the World (Fifth Edition). Belmont, CA: Wadsworth Cengage Learning.

Jenner, D. (2002). Experiencing and understanding mathematics in the midst of a story, Teaching Children Mathematics, 9(3), Reston, VA: National Council of Teachers of Mathematics, 167-170.

Jennings, C. M., Jennings, J. E., Richey, J., \& Dixon-Krauss, L. (1992). Increasing interest and achievement in mathematics through children's literature. Early Childhood Research Quarterly, 7(2), 263-276.

Kilpatrick, J., Swafford, J., \& Findell, B. (2001). Adding it up: Helping children learn mathematics. Washington, DC: National Academy Press.

Koirala, H. P., \& Bowman, J. K. (2003). Preparing middle level preservice teachers to integrate mathematics and science: Problems and possibilities. School Science and Mathematics, 145(10), 145-154.

Kolstad, R., Briggs, L., \& Whalen, K. (1996). Incorporating language arts into the mathematics curriculum: A literature survey. Education, 116, 423-532.

Krajewski, K., \& Schneider, W. (2009). Early development of quantity to number-word linkage as a precursor of mathematical school achievement and mathematical difficulties: Findings from a four-year longitudinal study. Learning and Instruction, 19, 513-526.

Kurz, T. L., \& Bartholomew, B. (2012). Supporting Math Skills with Children's Stories. Kappa Delta Pi Record, 48(4), 184-188.

Lowe, J., \& Matthew, K. (2000). Exploring math with literature. Book Links, 9(5), 58-59.

Lukić, D. (1967). Deca u ogledalu. Beograd: Mlado pokoljenje.

Malinović-Jovanović, N., \& Milojević, M. (2013): Priča i motivacija pri izgrađivanju i formiranju početnih matematičkih pojmova. u: S. Denić (ur.), Književnost za decu i njena uloga u vaspitanju i obrazovanju dece školskog uzrasta (176-188). Vranje: Učiteljski fakultet u Vranju.

Maričić, S., \& Purić, D. (2008). Poetski tekst kao integrativni elemenat aktivnosti vaspitača u razvoju govora i matematičkih pojmova, Zbornik radova Učiteljskog fakulteta, XI(10), 203-214.

Maričić, S., \& Purić, D. (2010): Brojalica u razvoju govora i razvoju početnih matematičkih pojmova. Zbornik radova Učiteljskog fakulteta, XIII(12), 179-188.

Maričić, S., \& Purić, D. (2013). Razvijanje matematičkih pojmova u integraciji sa razvojem govora posredstvom sadržaja iz književnosti za decu. u: M. Joković (ur.) Naše stvaranje: zbornik radova sa osmog simpozijuma sa međunarodnim učešćem „Vaspitač u 21. veku” (388-402), Aleksinac: Visoka škola za vaspitače strukovnih studija.

Maričić, S., \& Purić, D. (2014). Zastupljenost sadržaja iz književnosti za decu u predškolskom matematičkom obrazovanju. Zbornik radova Učiteljskog fakulteta, XVII(16), 177-190.

Marjanović, V. (2009). Poetika knjižeonosti za decu i mlade. Beograd: KIZ Centar. 
Marković, Ž. S. (1987). Zapisi o književnosti za decu. Beograd: Naučna Knjiga.

McDuffe, A., \& Young, T. (2003). Promoting mathematical discourse through children's literature, Teaching Children Mathematics, 9(7), 385-92.

Milenković, S. (2012). Metodika razvoja govora. Sremska Mitrovica: Visoka škola strukovnih studija za vaspitanje vaspitača.

Milinković, M. (1999). Horizonti detinjstva. Užice: Učiteljski fakultet u Užicu.

Milinković, M. (2012a). Knjižeonost za decu i mlade - poetika. Užice: Učiteljski fakultet u Užicu.

Milinković, M. (2012b). Bajkovite forme u knjižeonosti za decu i mlade. Užice: Učiteljski fakultet u Užicu.

Milutinović, I. Lj. (2016). Knjižeonost za djecu. Banja Luka: Univerzitet u Banja Luci, Filozofski fakultet.

Moyer, P. (2000). Communicating mathematically: Children's literature as a natural con- nection. The Reading Teacher, 54, 246-258.

National Association for the Education of Young Children \& National Council of Teachers of Mathematics (NAEYC \& NCTM) (2002). Position statement. Early childhood mathematics: Promoting good beginnings. (преузето 23.9.2016. https://www.naeyc.org/files/naeyc/file/ positions/psmath.pdf)

National Council for Teachers of Mathematics. (1989). Curriculum and Evaluation Standards for School Mathematics. Reston, VA.

Olujić, G. (1982). Poetika bajke. u: V. Marjanović (ur.): Dečja književnost u književnoj kritici (18-24). Beograd: Savremena administracija.

Petrović, T. (2005). Književnost za decu - Teorija. Sombor: Učiteljski fakultet.

Petrović, T. (2011). Uvod u književnost za decu. Novi Sad: Zmajeve dečje igre.

Purić, D., Maričić, S. (2012). Sadržaji iz književnosti za decu u razvoju matematičkih pojmova, u: N. Vulović (ur.): Metodički aspekti nastave matematike II (239-244). Jagodina: Fakultet pedagoških nauka.

Rogoff, B. (1990). Apprenticeship in thinking: Cognitive development in social context. Oxford, England: Oxford University Press.

Rosandić, D. (1984). Književnost u osnovnoj školi. Zagreb: Školska knjiga.

Rosen, D., \& Hoffman, J. (2009). Integrating concrete and virtual manipulatives in early childhood mathematics. Young Children, 64, 26-33.

Schiro, M. (1997). Integrating children's literature and mathematics in the classroom: children as meaning makers, problem solvers, and literary critics, New York: Teachers College Press.

Scott, Mac C. (2005). Kako čitati strip - nevidljivu umjetnost. Zagreb: Mentor.

Shatzer, J. (2008). Picturebook power: Connecting children's litera- ture and mathematics. The Reading Teacher, 81(8), 649-653.

Skoumpourdi, C., \& Mpakopoulou, I. (2011). The Prints: A Picture Book for Pre-Formal Geometry. Early Childhood Education Journal, 39, 197-206.

Smiljković, S. (2006). Autorska bajka. Vranje: Učiteljski fakultet u Vranju.

Smith, J. (1995) A different angle for integrating mathematics. Teaching Children Mathematics, 1(5), 288-94.

Stakić, M. (2013). Dečja recepcija književnog dela, u: M. Jovanović (ur.): Naše stvaranje, 12, 506-517. Aleksinac: Visoka škola za vaspitače strukovnih studija.

Stakić, M. (2014). The specifics of children's literature in the context of genre classification, Mediterranean Journal of Social Sciences, 5(19), 243-252.

Stone, J. (2016). Assessing the Impact of Picture Books in Primary Grades Mathematics Instruction (Doctoral Dissertations). University of Tennessee. Retrieved http:/ / trace.tennessee.edu/cgi/viewcontent.cgi?article=5229\&context=utk_graddiss

Šimić, G. (1998). Metodika razvijanja početnih matematičkih pojmova. Šabac: Viša škola za obrazovanje vaspitača.

Usnick, V., \& Maxson, S. (1996). Is Cinderella mathematically literate? The Clearing House, 70(1), 44-47.

Vacca, R. T., \& Vacca, J. L. (2005). Content area reading: Literacy and learning across the curriculum (8th ed.). Boston: Pearson Education.

Van den Heuvel-Panhuizen, M., \& Elia, I. (2011). Kindergartners' performance in length measurement and the effect of picture book reading. ZDM - The International Journal on Mathematics Education, 43(5), 621-635.

Van den Heuvel-Panhuizen, M., \& Elia, I. (2012). Developing a framework for the evaluation of picture books that support kindergartners' learning of mathematics. Research In Mathematics Education, 14(1), 17-47. 
Van den Heuvel-Panhuizen, M., Elia, I., \& Robitzsch, A. (2016). Effects of reading picture books on kindergartners' mathematics performance, Educational Psychology, 36(2), 323-346. doi:10.1080/01443410.2014.963029

Vuković, N. (1996). Uvod u književnost za djecu i omladinu. Podgorica: Unireks.

Ward, R. A. (2005). Using Children's Literature to Inspire K-8 Preservice teachers' future mathematics pedagogy. The Reading Teacher, 59(2), 132-143.

Welchman-Tischler, R. (1992). How to Use Children's Literature to Teach Mathematics (NCTM How to Series). Reston, VA: National Council of Teachers of Mathematics.

Whitin, D., \& C. Gary. (1994). Promoting mathematical explorations through children's literature. Arithmetic Teacher 41(March), 394-400.

Whitin, D., \& Whitin, P. (2004). New Visions for Linking Literature and Mathematics. The National Council of Teachers of English.

Whitin, D., \& Wilde, S. (1992). Read any good math lately? Children's books for mathematical learning, K-6. Portsmouth, NH: Heinemann.

Whitin, P., \& Whitin, D. J. (2011). Mathematical Pattern Hunters. Young Children, 66(3), 84.

Worley, J. (2002). Using Literature to Teach Math and Science. Retrieved from http://www.rgs.uky.edu/odyssey/fallo2/usingliterature.html.

Zazkis, R., \& Liljedahl, P. (2009). Teaching Mathematics as Storytelling. Sense Publishers, Rotterdam, The Netherlands.

Tucker, C., Boggan, M., \& Harper, S. (2010). Using children's literature to teach measurement, Reading Improvement, 47(3), 154-161.

\section{http://www.ejmste.com}

